\title{
Memory AND Promise in ARENDT AND Nietzsche
}

\author{
VANESSA LEMM \\ Universidad Diego Portales, Chile
}

\begin{abstract}
Resumen
Este artículo compara el valor y el significado que Arendt y Nietzsche otorgan a la memoria y a la promesa para la constitución de lo político así como para la salvaguardia de la libertad y de la pluralidad humana.

Abstract

This article investigates and compares the value and significance that Arendt and Nietzsche attribute to the role played by memory and by the promise in constituting the political and in safeguarding the freedom and plurality of human action.
\end{abstract}

\section{PALABRAS CLAVE • Arendt • Nietzsche • Promesa • Memoria • Olvido}

This article compares Arendt's and Nietzsche's conceptions of the political, not in order to emphasize their similarities i.e., that in the devaluation of the political they both see one of the chief problems of modernity, but rather to investigate their divergence when it comes to the question of how to re-establish the value of the political. ${ }^{1}$ The most striking difference between Arendt's and Nietzsche's conception of the political is the importance that each attributes to memory and to forgetfulness. While Arendt's writings on politics are literally full of references to the value of memory in politics, Nietzsche's writings are rich with praise for the virtues of forgetfulness.

Arendt's strong emphasis on the importance of memory in politics derives from her experience of totalitarianism. This experience cannot and should not be forgotten, and because it cannot be forgotten, it will always remain with us. The survival of the memory of totalitarianism is crucial for Arendt because she believes that the future of politics depends on it. On the contrary, in Nietzsche, the future of politics rests not only on the ability of memory, but also and more importantly on that of forgetfulness. This is not to suggest that totalitarianism should be forgotten, but rather, that forgetfulness is needed in order to preserve a memory of the past that is vital to the future. The different strategies proposed by Arendt and Nietzsche in order to address the question of how to preserve a past that is vital to the future are reflected in their different conceptions of the promise.

This article begins with Arendt's notion of the promise and then turns to that of Nietzsche. To her credit, Arendt has brought back the centrality of the promise in contemporary political philosophy (Arendt, 1958: 243-248). In The Human Condition, she introduces the promise and 
forgiveness as remedies for the irreversibility and the unpredictability of the processes started by human action:

These moral precepts [the promise and forgiveness] are the only ones that are not applied to action from the outside, from some supposedly higher faculty or from experiences outside action's own reach. They arise, on the contrary, directly out of the will to live together with others in the mode of acting and speaking. If without action and speech, without the articulation of natality, we would be doomed to swing forever in the ever-recurring cycle of becoming, then without the faculty to undo what we have done and to control at least partially the processes they have let loose, we would be the victims of an automatic necessity bearing all the marks of the inexorable laws which, according to the natural sciences before our time, were supposed to constitute the outstanding characteristic of the natural process (Arendt, 1958: 246). ${ }^{2}$

The "faculty to make and keep promises" responds to the frailty of human affairs (Arendt, 1968: 164). In the "ocean of uncertainty", which is the future, promises serve to set up those "islands of security" that assure the continuity and the durability of human relationships (Arendt, 1958: 244). The promise stabilizes the world of human affairs and protects it from the unforeseeable consequences of human action essentially because it is a mechanism that controls the future. According to Arendt, the promise understood as a mechanism of control over the future lies at the basis of every polity that arises out of "the will to live together with others in the mode of action and speech" (Arendt, 1958: 246). ${ }^{3}$ As such the promise constitutes a bilateral commitment and guarantee which binds people together through an agreed purpose.

Control over the future succeeds due to a particular kind of memory. For Arendt, the faculty of promise is essentially a faculty of memory that has the power to bring a body of people back to their beginning, that is, back to the moment when they agreed on an aim and a purpose. In this sense, the promise is a reminder that keeps on bonding the group together and linking the individual back to a past from which it began and from which it can begin again. This is why, for Arendt, the promise is not applied to action from the outside but is itself an "articulation of natality". The promise exercises control over the future by means of drawing the future ever further into the past. In so doing, the promise reverses the flow of time. Thus, instead of being born into an uncertain future, one is born into a secured past.

Arendt praises the human capacity to make promises and to dispose of the future as if it were past, because she sees in the latter a people's source of sovereignty. It is important to note that Arendt is generally known for her anti-sovereign conception of politics according to which "if men wish to be free, it is precisely sovereignty they must renounce" (Arendt, 1968: 165). Sovereignty has to be rejected because it stands for a will power over oneself or over others which is inseparable from violence and domination. ${ }^{4}$ In her discussion of the promise, however, Arendt

2 For reasons of space Arendt's notion of forgiveness cannot be discussed here. On my reading of forgiveness in Arendt see also Footnote No. 27.

3 See also "All political business is, and always has been, transacted within an elaborate framework of ties and bonds for the future -such as laws and constitutions, treaties and alliances- all of which derive in the last instance from the faculty to make and to keep promises in the face of the essential uncertainties of the future" (Arendt, 1968: 164).

4 "The famous sovereignty of political bodies has always been an illusion, which, moreover, can be maintained only by 
explicitly uses the term "sovereignty" in order to signify exactly the opposite, namely, that the sovereignty of a body of people, bound and kept together by an agreed purpose for which alone promises and contracts are valid and binding is preferable to being completely free, unbound by any promise and not kept by any purpose (Arendt, 1958: 245). That "human sovereignty" and the "the faculty of making promises" are connected to each other is in an idea Arendt takes from Nietzsche. In a famous passage from On the Genealogy of Morals, Nietzsche names the promise which binds people together in a group "the memory of the will" (Gedächtnis des Willens) (Nietzsche, 1994: 39).

Arendt acknowledges that "Nietzsche saw with unequaled clarity the connection between human sovereignty and the faculty of making promises, which led him to a unique insight into the relatedness of human pride and human conscience" (Arendt, 1958: 241). Unfortunately, for Arendt, this connections "remained unrelated with and without effect upon his chief concept, the 'will to power', and therefore are frequently overlooked even by Nietzsche scholars" (Arendt, 1958: 241). Viewed from the perspective of will to power, Arendt argues that the promise of the sovereign individual in Nietzsche, which she identifies as the "memory of the will", characterizes the will power of the isolated individual and not the will power of the many bound together. Therefore, the sovereignty that is associated with the privilege to make promises in Nietzsche is not only inherently a- and possibly even anti-political, but also necessarily egoistic and ultimately unfree. On Arendt's assumption that freedom arises from the power of the "We" rather than from the will power of the isolated individual, the figure of the sovereign individual in Nietzsche becomes the paradigmatic example of a genuine lack of freedom resultant from a devaluation of the political. ${ }^{5}$

In order to judge the merit of Arendt's interpretation of Nietzsche, it is necessary to return to the Nietzschean text, in particular, to the opening sections of the second essay of On the Genealogy of Morals. The question is not simply whether Arendt's appropriation of Nietzsche's notion of the promise is correct, but more significantly, whether a different reading of Nietzsche might be useful in order to address some problems found in Arendt's own account of promising. The problems I see in Arendt's account of the promise are threefold. All three revolve around her definition of the promise exclusively in terms of memory. First, her understanding of the promise in terms of a commitment to the past stands in tension with her understanding of freedom as the power to begin (Arendt, 1968: 165-171). Arendt argues correctly, in my opinion, that every beginning is a re-beginning and hence requires a return to the past that involves a form of memory of the past. But what remains unclear is how a return to the past alone can generate a new beginning, or, in

means of violence, that is, with essentially non-political means. Under human conditions, which are determined by the fact that not man but men live on earth, freedom and sovereignty are so little identical that they cannot even exist simultaneously. Where men wish to be sovereign, as individuals or as organized groups, they must submit to the oppression of the will, be this, the individual will with which I force myself, or the 'general will' of an organized group. If men wish to be free, it is precisely sovereignty they must renounce". (Arendt, 1968: 164-165).

5 The other paradigmatic example of a form of sovereignty that threatens the political, according to Arendt, is found in Rousseau's notion of the promise known as the "general will". While Nietzsche's notion of "the sovereign individual" reflects a form of violence the individual exercises against itself, Rousseau's notion of the "general will" reflects a form of violence some exercise over others (On sovereignty and promise in Nietzsche and Rousseau, see also Ansell-Pearson, 1991). For Arendt, both notions are inherently tyrannical (Arendt, 1968: 164). In contraposition to Nietzsche and Rousseau, Arendt sees in her own conception of the promise an expression of the freedom and the power of the "We" that protects the sphere of politics against the forms of violence and domination, which are, in her view, present in Nietzsche's and Rousseau's notion of promise. 
other words, how the past can renew itself by itself. From the perspective of memory, as Arendt defines it, it seems that a beginning anew is never really new, but always only a return to a past that one increasingly remembers. For Arendt, this return to the past is a return to the beginning which allows one to re-begin because what one returns to is essentially the memory of the human being as a beginner. She claims that "because he is a beginning, man can begin; to be human and to be free are one and the same" (Arendt, 1968: 167). The question remains, however, how the memory of the human being as a beginner can lead to the actual act of beginning - how Arendt envisages the transition from memory, understood as a holding on to the past, to action understood as the spontaneous letting loose of processes into future.

A second problem also emerges from her definition of the promise in terms of memory, namely, her claim that the promise needs to be institutionalized, or, in other words, that freedom needs to be founded (Arendt, 1965: 141-214). Arendt defends the contingency of the public realm by holding that the unreliability of human action is the price that has to be paid for freedom and that the impossibility of predicting the consequences of action is the price that has to be paid for plurality (Arendt, 1958: 175-181). Nevertheless, she contends that humans cannot live together without some stabilizing measures. Hence, she defends the institution of memory as a means to secure the power of the group against the uncertainties of the future. The question is whether this institutionalized protection not only preserves freedom and plurality, but simultaneously threatens them assuming that institutionalization is essentially a mechanism of control directed against the unreliability and unpredictability that define the freedom and plurality of human action.

Finally, built upon the first two questions is a third. Is the promise understood, on the one hand, as the drawing of the future into the past and, on the other, as the institutionalization of the past over the future, not inherently violent and thus in conflict with Arendt's conception of action and speech as non-violence? For Arendt, tying the future back to the past in order to give stability should be the role of authority (Arendt, 1968: 91-141). Although Arendt opposes authority to violence, doubts may be raised as to whether this opposition is not undone in her idea of the promise. Interestingly, Arendt consistently employs expressions such as "to make a promise", and to "keep a promise" but does not comment on her own use of metaphors that clearly belong to what she terms "the realm of making" (Arendt, 1958: 136-174). The metaphoric expressions of common language used by Arendt point to manual activities: to making, holding, keeping; to something one does with the hands rather than with faculties of the mind. These expressions also reveal the presence of force over oneself and over others: to promise means to hold on to something rather than to let it go; to keep something in one's firm grip, rather than to let it loose; to make oneself and others remember rather than forget; to force something into existence that would otherwise not have occurred. Because Arendt argues that violence is at stake whenever the grammar of making is projected onto that of politics (Arendt, 1958: 220-230), it seems that her own definition of the making of promises is violent as opposed to non-violent. Hence, the question is of how to counter-act the violence involved in the making of promises at the moment of the foundation of political power, as well as in the stabilization of political power.

This question lies at the heart of Nietzsche's conception of the promise. In On the Genealogy of Morals, Nietzsche asks whether the task "to breed an animal which is able to make promises" does not constitute "the real problem of human beings?" (Nietzsche, 1994: 38). He considers this task to be a "paradoxical" one because it requires the human animal to reverse its animal nature. The 
human being, a forgetful animal, has to become the opposite, a reliable one. Nietzsche associates the forgetfulness of the human animal with a state of "robust health" that is characteristic of a solitary way of life (Nietzsche, 1994: 39). According to his genealogical discourse, however, the human animal could not maintain its animal forgetfulness due to its relative inferiority compared with other forms of animal life. In order to survive humans had to become social and group-conscious animals. Nietzsche contends that this transformation was accomplished through the imposition of a "memory of the will" (Gedächtnis des Willens) on the forgetfulness of the human animal and that the latter coincides with the institution of social and political forms of life. ${ }^{6}$

Although Nietzsche seems to privilege the life form of the solitary and forgetful animal to that of the "herd animal", he acknowledges that the memory of the will responds to a need of life and that therefore its political institution is not only necessary for the preservation of human animal life, but that its accomplishments are also praiseworthy. ${ }^{7}$ However, the successful institution of the memory of the will "seem all the more surprising to the one who [like Nietzsche] can fully appreciate the countervailing force, forgetfulness" (Nietzsche, 1994: 38). From the perspective of forgetfulness, the memory of the will only solves the problem of bringing forth an animal that can make promises "to large degree" (Nietzsche, 1994: 38). It provides a solution to the question of how societies can be kept together, how forgetful and solitary animals can be made to dedicate themselves willingly to the welfare of society and of the state, but since it fails in valorizing animal forgetfulness, the memory of the will is not entitled to the privilege of making promises. On the contrary, the memory of the will carries the risk of producing an inherently irresponsible and dangerous animal: an over-bred herd animal, too obedient and too tame, an animal whose promises cannot be trusted. ${ }^{8}$ And hence, for Nietzsche, the question remains of how to bring forth a form of memory and promise that despite its being directed against forgetfulness recognizes

"And precisely this necessarily forgetful animal, in whom forgetting is a strength, representing a form of robust health, has bred for itself a counter-device, memory, with the help of which forgetfulness can be suspended in certain cases, -namely in those cases where a promise is to be made: consequently, it is by no means merely a passive inability to be rid of an impression once it has made its impact, nor is it just indigestion caused by giving your word on some occasion and finding you cannot cope, instead it is an active not-wanting-to-let-go, a will to keep on wanting what has been, on some occasion, willed, a real memory of the will (Gedächtnis des Willens)" (Nietzsche, 1994: 39).

7 Nietzsche's notion of the memory of will is in this sense comparable to his notion of antiquarian history developed in On the Use and Disadvantage of History for Life (Nietzsche, 1997: 72-75). Both are forms of memory that are advantageous for life because they preserve the past, that is, the traditions, habits, rules and norms of any given society.

$8 \quad$ Nietzsche holds that the memory of the will is designed to fabricate an identity and to keep the human animal identical to itself, identical to a social and civilized self forced on it. But to turn the human animal into something identical and generally identifiable is a means to gain mastery over life and future life. T. W. Adorno and M. Horkheimer see in this process of identification a reflection of the "dialectic of enlightenment"which marks the "course of European civilization": "What was different is equalized. That is the verdict which critically determines the limits of possible experience. The identity of everything with everything else is paid for in that nothing may at the same time be identical with itself. Enlightenment dissolves the injustice of the old inequality - unmediated lordship and mastery - but at the same time perpetuates it in universal mediation, in the relation of any one existent to any other. It does what Kierkegaard praises his Protestant ethic for, and what in the Heraclitean epic cycle is one of the primal images of mythic power; it excises the incommensurable. Not only are qualities dissolved in thought, but men are brought to actual conformity" (Horkheimer and Adorno, 2002: 12). Nietzsche, like Adorno and Horkeimer after him, rejects the politics of identity inherent to the process of socialization and civilization. The opposite view, namely, that Nietzsche is a proponent of a politics of identity is found in Dombowsky, 2000: 283. On Nietzsche as a critic of the politics of identity, see also Schrift, 2000: 292. 
in forgetfulness a force necessary not only to the becoming of human animal life, but also to the constitution of social and political forms of life. ${ }^{9}$

It is interesting to note that in Nietzsche scholarship the "memory of the will" is primarily known for the violence and cruelty involved in its making. Arendt, instead, praises the greatness and sovereignty which results from the making and keeping of promises, despite the fact that Nietzsche emphasizes "how much blood and horror lies at the basis of all 'good thing'!" (Nietzsche, 1994: 42):

'How do you give a memory to the animal? How do you impress something on this partly dull, partly idiotic, inattentive mind, this personification of forgetfulness, so that it will stick?'... This age-old question was not resolved with gentle solutions and methods, as can be imagined; perhaps there is nothing more terrible and strange in the human prehistory than its technique of mnemonics... The human being was eventually able to retain five or six 'I-don't-want-tos' in its memory in connection with which a promise had been made, in order to enjoy the advantages of society -and there you are! With the aid of this sort of memory, people finally came to 'reason'!- Ah, reason, solemnity, mastering of emotions, this really dismal thing called reflection, all these privileges and splendors humans have: what a price had to be paid for them! How much blood and horror lies at the basis of all 'good things'! (Nietzsche, 1994: 42)

That Arendt does not comment on the violence and cruelty inherent to the making of the "memory of the will" in Nietzsche is not surprising. After all, she identifies the memory of the will with the will power of the sovereign individual and opposes the latter's violence to the non-violence of the promise that keeps the group bound together and that arises out of the will to live together with others in the mode of action and speech.

Nietzsche, instead, clearly distinguishes "the promise of the sovereign individual" as that which overcomes the "memory of the will". The sovereign individual is "an autonomous, supra-ethical individual", who deserves "the privilege to make promises" because it "has freed itself from the morality of customs" (Nietzsche, 1994: 40). I argue that the sovereign individual's overcoming of the memory of the will depends on a return of animal forgetfulness as that force which allows the individual to twist free from the morality of custom. ${ }^{10}$ The sovereign individual forgets the moral and political norms of society in the name of its "own standard of value" (Nietzsche, 1994: 40). This forgetfulness reflects not only the sovereign individual's own becoming and self-overcoming, but moreover, contributes, as I shall argue below, to the transformation of given social and political forms of life (morality of custom). ${ }^{11}$

$9 \quad$ On the value of forgetfulness and memory in the Greek polis, see Nicole Loreaux (1997) who shows that in the polis the oath serves as a means against discord only insofar as it is tied to forgetfulness as that force which dissolves the memory of misdeeds and hatred. According to Loreaux, the oath (promise) safeguards the stability and harmony of the Greek polis because it reflects a commitment to forget rather than to remember. On forgetfulness and promise in Nietzsche, see also Schaap (2002).

10 I borrow the term "twisting free" as a synonym for the Nietzschean term "Überwindung" and "Selbstüberwindung" from Sallis (1991).

11 On the importance of forgetfulness for the becoming (and overcoming) of human animal life, see Schrift (2001: 47-62). Schrift argues that it is the emphasis on becoming that is at stake in the discussion, at the opening of the second essay of the Genealogy of Morals, on the active forgetting of the sovereign individual who has earned the right to 
Arendt's identification of the "memory of the will" with the will power of the sovereign individual in Nietzsche is problematic. First of all, this identification ignores the fact that Nietzsche actually rejects the "memory of the will" precisely because of the cruelty and violence he detects in the mechanisms of its making. Second, and perhaps more importantly, his conception of the promise of the sovereign individual constitutes a critique of the "memory of the will" that is inherently political. It seeks to overcome a politics of violence and domination through the cultivation of individual freedom and responsibility. Arendt's misreading of Nietzsche fails to differentiate between the "memory of the will" as a means of domination and the promise of the sovereign individual as a means of freedom and responsibility. ${ }^{12}$

In Nietzsche, the crucial question of the promise is not, as Arendt claims, how to generate, preserve and protect the memory of the will that lies at the basis of political power, but instead, how to counter-act the violence and domination which define the political practices of institutions such as the modern state. This is not to say that Nietzsche objects to the need for political institutions as such. On the contrary, he welcomes strong institutions, ${ }^{13}$ but he believes that they require a counter-force which continuously overcomes their being founded on violence and domination. For him, the promise of the sovereign individual is a counter-promise to the "memory of the will" which protects the freedom and plurality of human action through the practice of what could be called an agonistic politics of responsibility. Responsibility is agonistic in the sense that it stands for a continuous resistance to the institutionalization of freedom. In this view, freedom is neither what one has by virtue of an instituted right nor what one is given by virtue of a mutual agreement, but always only what one fights for, what one conquers (Nietzsche, 1990: 103-104).

What distinguishes the political value of the agonistic spirit exemplified in the promise of the sovereign individual, as opposed to the promise in Arendt, is not institutionalization: for Nietzsche, the promise is inherently counter-institutional. Its function is to submit the established authority of the memory of the will and its moral and political standards to a continuous and radical critique. It is by means of critical questioning, rather than by means of tyrannical self-discipline, that Nietzsche hopes to advance human sovereignty and greatness. It is because of this agonistic spirit that several authors have tried to assimilate Nietzsche to an agonistic conception of democracy.

make promises: "It is only in the case of this 'emancipated individual' (Freigewordene) -this 'master of the free will' (GM II, 2: Herr des Freien Willen) who is capable of becoming other than he was by forgetting what he was- that promising becomes a praiseworthy act of responsibility" (Schrift, 2001: 59).

12 Nietzsche's notion of the promise of the sovereign individual is comparable to the pact between Abraham and God as it is articulated by Kierkegaard in Fear and Trembling. While Arendt uses the example of the pact between Abraham and God in order to show that true freedom is never that of the individuals' will but always what emerges out of an agreement with others (Arendt, 1958: 243-4), Kierkegaard turns to the figure of Abraham in order to show exactly the opposite: true freedom is possible only on the basis of an essential disagreement between the individual and the ethical community. True freedom in Kierkegaard can not, therefore, be achieved by the means of politics or by the means of agreement and consensus within an ethical community, but always only through an experience of faith. Faith in Kierkegaard is the carrier of genuine freedom, where freedom stands for the strength to break with the ethical community in the name of one's singular responsibility (Kierkegaard, 1985). The virtues Kierkegaard attributes to Abraham are similar to those Nietzsche attributes to the sovereign individual: both "suspend the ethical", in Arendt's terms the power of the We, in the name of individual freedom as responsibility. On responsibility in Kierkegaard, see also Derrida, 1992.

13 Nietzsche emphasizes, for example, the will to authority, tradition and solidarity over centuries defining Roman politics as particularly life-enhancing (Nietzsche, 1990: 104-106). On Nietzsche's reverence for political institutions, see Honig, 1993: 69-75. 
While some argue that an agonistic conception of political action is essential to the political life within a democracy, others argue that agonistic political action cannot be institutionalized and hence always only "attacks" political institutions, whether democratic or not, from the outside and that it is this anti-institutional aspect of Nietzsche's agonistic politics which inspires hope for a democracy "yet to come" (Nietzsche, 1986: 384). ${ }^{14}$

Moreover, the promise of the sovereign individual is important to Nietzsche not because it reflects a commitment of the self to itself that is inherently a- and maybe even anti- political, but, on the contrary, because it stands for the cultivation of a free relation with the other which exceeds the project of individual self-realization. Since Arendt confuses Nietzsche's notion of the will to power with that of the individual's will, she takes his notion of sovereignty to be entirely concerned with individual self-realization. ${ }^{15}$ Thus, she fails to see both that the promise of the sovereign individual reflects a preoccupation with the cultivation of freedom as responsibility that overcomes the kind of individualism which devalues the political, on the one hand, and that overcomes the kind of politics which devalues the freedom and plurality of human action, on the other.

Arendt's reading of Nietzsche is typical of an interpretation that identifies the promise of the sovereign individual as essentially a-social and a-political because it appears in the form of egoism and solitude. ${ }^{16}$ In reality, Nietzsche defends egoism and solitude only because they are the conditions that allow the human animal to stand in a relation to the other which is neither grounded on force and fear, nor on resentment and revenge (Nietzsche, 1995: 93-96). The promise of the sovereign individual is a carrier of unlimited responsibility because it reflects a power that results from the overcoming of the need to dominate others. ${ }^{17}$ Responsibility is the privilege of those who give and promise to the other and who see in this gift and giving the greatest extension of their power.

Interestingly, Nietzsche associates this gift-giving with a return of animal forgetfulness (Nietzsche, 1995: 74-79). ${ }^{18}$ Gift-giving is an excessive, prodigal and wasteful force constituted by the individual's

Thematizing the value of anti-institutional culture for politics, Brown argues that "permanent resistance to the state that both limits and ensures the democratic form becomes a means of sustaining democracy insofar as it is the state form that dissolves democracy. Only through the state are the people constituted as a people; only in resistance to the state do the people remain a people" (Brown, 2000: 205-223). On agon and politics in Nietzsche, see also Villa, 2000: 224-246; Honig, 1993; Hatab, 1995 and 2002: 132-147 and Acampora, 2003: 374-390. In contraposition to the above, Conway argues that the agonistic spirit does not permeate society as a whole, but merely defines "the community of agonistic 'friends' founded by the Übermensch" (Conway, 1997: 31), which itself stands at the pinnacle of a pyramidal hierarchy of ethical communities. In Conway's view, agonism is significant insofar as it furthers the (sovereign) individual's moral perfection (for a similar view, see also Owen, 2002: 113-131). Against Conway, Siemens convincingly argues that agon should not be restricted to the circle of enemy-friends formed around the overhuman (Conway, 1997: 24), but is a constituent of society as a whole (Siemens, 2002: 84). Siemens does not, however, identify agon as a struggle for and against rule. Rather he sees in agon the origin and the measure of the social and political forms life as well as of ethical laws (Siemens, 2002: 91-106). For an interpretation of agon in Nietzsche as a constituent of social and political forms of life, see also Gerhardt, 1983: 111-133 and Siemens, 2001: 80-106.

15 For another instance of this confusion in Arendt, see also: "In other words, will, will-power, and will-to-power are for us almost identical notions; the seat of power is to us the faculty of the will as known and experienced by man in his intercourse with himself" (Arendt, 1968: 160).

16 This view is not only found in Arendt but also, for example, in Macintyre, 1984.

17 Norris argues that power in the noble (sovereign individual) is "a pure discharge of vitality and power, which does not have as its aim the domination of the minds and souls of others" (Norris, 1985: 4). On sovereignty in Nietzsche as an overcoming of domination, see also McIntyre, 1997: 3-21.

18 On gift-giving in Nietzsche, see Shapiro (1991), Schrift (1995 and 1996: 197-205). On the relation between gift-giving and forgetfulness, see Derrida (1992a: 17-18) and Schrift (1995: 204, no. 12). 
forgetting of its self, which, in the words of Zarathustra, is a "going-under": "I love him whose soul is overfull so that he forgets himself and all things are in him: thus all things spell his going under" (Nietzsche, 1995: 16). ${ }^{19}$ The sovereign individual's forgetfulness is an overflowing of the self that reminds us of the tragic hero's going-under (Untergang) as the going-over (Übergang) to something that exceeds the hero's self (Nietzsche, 1997: 155). ${ }^{20}$ Both reveal the traces of a return of animal forgetfulness as that force which disrupts an economy of survival (the memory of the will) in the name of a giving beyond measures (the promise of the sovereign individual). ${ }^{21}$ Accordingly, the "high" point of freedom in Nietzsche is always a going-under of the self before the other rather than a rising of the self above the other. The promise of the sovereign individual attains such a high value for Nietzsche only insofar as the freedom it exemplifies stands for a radical exposure of the self to the other that takes the form of unlimited responsibility and self-responsibility.

In On the Genealogy of Morals, Nietzsche shows that the making of the memory of the will coincides with the forced breeding of a particular kind of animal, namely, a social and civilized animal that is inherently reliable, predictable and entirely devoted to the good of society. Furthermore, he maintains that the violence which characterizes the making of the memory of the will is inseparable from a form of violence directed against the animality of the human animal, in particular, against its animal forgetfulness. ${ }^{22}$ The memory of the will, as Arendt correctly sees, humanizes an animal characterized by forgetfulness, or, as she puts it, distinguishes "humans from animal life" (Arendt, 1958: 241). For Arendt, the distinction between human and animal life is crucial: it constitutes the condition of possibility of politics, that is, of human freedom and action. Otherwise, as Arendt notes, "we would be doomed to swing forever in the ever-recurring cycle of becoming"; "we would be the victims of an automatic necessity" (Arendt, 1958: 241).

While Arendt believes that a separation of human from animal life is the only way to protect freedom and plurality, Nietzsche believes exactly the opposite. He contends that this separation threatens the freedom and plurality of human action. For Nietzsche, the problem is not the violence of the animal, for he considers the animal to be inherently innocent, but, instead, the problem lies with the violence that humans direct against their own animality and their animal forgetfulness. ${ }^{23}$ Since Nietzsche considers animal forgetfulness to be essential to the enhancement of

19 The notion of the "gift-giving virtue" in Nietzsche has a strong affinity with Bataille's notion of "unproductive expenditure". In both authors "wealth appears as an acquisition to the extent that power is acquired by a rich man, but it is entirely directed towards loss in the sense that this power is characterized as power to lose. It is only through loss that glory and honor are linked to wealth". (Bataille, 1985: 122).

20 "The heroic human being despises his happiness and his unhappiness, his virtues and vices, and in general the measuring of things by the standard of himself ... His strength lies in forgetting himself" (Nietzsche, 1997: 155).

21 A relation to the other that is free from domination is also exemplified by the Nietzschean figure of the "genius of culture": "Of what account is genius if it does not communicate to the one who contemplates and reveres it such freedom and elevation of feeling that one no longer has need of genius! - Rendering themselves superfluous (sich überflüssig machen) - that is the glory of the great (Nietzsche, 1986: 298; 1990: 108-109)". Hatab objects to the view that the sovereign individual foreshadows Nietzsche's creator type. According to him, "such a connection is quite problematic because of the meaning of 'sovereignty' its textual association with morality, and Nietzsche's critique of modernist freedom" (Hatab, 1995: 38).

22 Examples from Nietzsche's early and late work confirm that what defines the politics of the memory of the will is a "continued cruelty to animals" (Nietzsche, 1997: 164). See also, "struggling 'civilization' (taming) needs every kind of irons and torture to maintain itself against terribleness and beast-of-prey natures" (Nietzsche, 1968: 466).

23 Whereas violence has been traditionally attributed to the animal, Nietzsche attributes it to the human, in particular to the project of the human animal's civilization and moralization, a project Nietzsche's sees carried out through 
human animal life, for him, the question is how to make a promise that protects the freedom and plurality of human action without resting on violence and domination exercised over the human animal's animal life.

On this reading, when the human animal defines itself against its animality and animal forgetfulness, or denies it a productive role, cultural and political life assumes forms that are based on domination and exploitation of humans by humans. The breeding of the "memory of the will" as an attempt to transcend or extirpate animality and animal forgetfulness is an example of these forms of domination. Contrariwise, when the human animal engages with its animality and animal forgetfulness, this gives rise to forms of cultural and political life that are rooted in the singular human animal's responsibility. Nietzsche's conception of the promise of the sovereign individual is an example of a form of memory that fruitfully engages with the human animal's animality.

In the sovereing individual, memory is not imposed on the human animal's forgetfulness. Instead, the promise of the sovereign individual portrays the features of animal forgetfulness. In the sovereign individual, reliability and predictability are not forced, but manifest themselves in the sovereign individual's "instinct" of responsibility (Nietzsche, 1994: 40). ${ }^{24}$ Nietzsche sees in the fact that an individual must act in the name of its responsibility a sign that sovereignty and greatness have been achieved. The individual's instinct of responsibility should not be confused with its will power: what makes for sovereignty in Nietzsche is not the fact that the individual is free and could have acted otherwise, but that it is subject to the necessity of responsibility and hence could not have acted otherwise. Nietzsche contests the Christian ideal of moral responsibility which rests on the belief that human action results from the individual's freedom of the will (Nietzsche, 1968: 64-65). Genuine responsibility, instead, occurs when views such as the latter have been overcome. Responsibility in the sovereign individual is promising because it is immoral or amoral, rather then moral; unconscious rather then conscious; instinctive rather then reflected; necessary rather then free; a form of forgetfulness rather then a form of memory. ${ }^{25}$

According to my interpretation of Nietzsche, it is a mistake to think that the promise constitutes a "faculty", a self-sufficient power, cut off from life. For Nietzsche, the promise is a force of life that has to be investigated from the perspective of life as will to power. ${ }^{26}$ The perspective of life as will to power reveals that the promise is not a form of memory, but, on the contrary, that every promise reflects an antagonistic involvement of memory for and against forgetfulness. In this sense, every promise is not simply a form of memory turned towards the past, as Arendt suggests, but also a form of forgetfulness turned towards the future. Accordingly, Nietzsche distinguishes

the "ascetic priest": "Morality is a menagerie; its premise, that iron bars are more useful than freedom, even for the captive; its other premise, that there are animal tamers who do not shrink from frightful means, who know how to handle red-hot iron. This horrific species, which accepts battle with the wild animal, calls itself 'priest'” (as cited by Norris, 1985: 9-11). On the restoration of animal violence to its amoral innocence, see Norris (1985: 9-11).

"The proud realization of the extraordinary privilege of responsibility, the awareness of this rare freedom and power over himself and his destiny, has penetrated him to the depth and become an instinct, his dominant instinct" (Nietzsche, 1994: 40).

25 Nietzsche, generally speaking, privileges the unconscious over consciousness. On the emergence of consciousness and its relation to the human animal's humanization, socialization and civilization, see in particular Nietzsche, 2001: 30-32, 35, 37.

26 Accordingly, also memory in Nietzsche should neither be understood as a faculty in the Kantian sense nor as a selfsufficient organ. On life and memory, see also Stiegler (2001: 58-74). 
between two kinds of promises. The first kind of promise indicates a 'victory' of memory over forgetfulness. This promise is, as in Arendt, made in the name of the past. It is, like the memory of the will, a means to stabilize and to secure the continuity of the past, the present and the future against the uncertainties of the future. The second kind of promise is exemplified by the promise of the sovereign individual (and the overhuman). It indicates a 'victory' of forgetfulness over memory. This promise is made in the name of the future. It is a means not only to break with the past, but also to revolutionize the present in view of future life to come. Against the dangers inherent in a politics where the past dominates the future, this promise welcomes the return of animal forgetfulness as that force which disrupts the identity between past, present and future in the name of the free and spontaneous generation of life. Both kinds of promises - the ones that stabilize and secure the rule of the group and the ones that revolutionize it - are, according to Nietzsche, of equal value to human animal life. Depending on whether life needs to be preserved or whether life needs to be renewed, either the first or the second kind of promise protects the freedom and plurality of human action.

From the perspective of Nietzsche's conception of the promise, the questions addressed at the beginning to Arendt's notion of the promise arise from an insufficient consideration of the value of forgetfulness. First, forgetfulness constitutes the missing link between the memory of the human being as a beginner and the actual act of re-beginning. ${ }^{27}$ On Nietzsche's account, what allows one to re-begin is forgetfulness because every action requires forgetfulness (Nietzsche, 1997: 62). Furthermore, what protects the freedom and plurality of human action against the dangers of authority, that is, of a politics dominated by the institution of the past over the future, is a promise that knows how to disrupt the "memory of the will" in the name of the future. In Nietzsche, such a promise has the power to revolutionize an institution in such a way that the latter can itself remain faithful to the task of protecting and preserving the freedom and plurality of human action. Lastly, what redeems the human animal from the violence involved in the making of the memory of the will is a promise that opens up a free and non-violent relation to the other, a relation that does not stand under the rule of the human animal's forced civilization and humanization.

Finally, I would like to return to the question raised at the beginning, namely, of how to preserve the survival of the memory of totalitarianism in a way that secures the future of politics, of human freedom and plurality. In my opinion, both Arendt and Nietzsche have a valid point because both the memory of the will and the promise of the sovereign individual are needed in order to preserve the memory of totalitarianism. On the one hand, Arendt is right in asserting that it is the task of a democratic polity to generate, preserve and protect the survival of the memory of totalitarianism by means of instituted forms of memory. But, on the other hand, Nietzsche persuasively shows that it is the promise of the sovereign individual that allows us to question the institutions of the present in the light of the memory of totalitarianism, thus protecting us from totalitarianism's return. 


\section{REFERENCES}

Acampora, Christa. 2003. "Demos Agonistes Redux: Reflections on the Streit of Political Agonism". Nietzsche-Studien (32): 374-390.

Ansell-Pearson, Keith. 1991. Nietzsche Contra Rousseau. Cambridge: Cambridge University Press.

Ansell-Pearson, Keith. 1994. An Introduction to Nietzsche as a Political Thinker. Cambridge: Cambridge University Press. Arendt, Hannah. 1958. The Human Condition. Chicago: University of Chicago Press.

Arendt, Hannah. 1965. On Revolution. London: Penguin Books.

Arendt, Hannah. 1968. "What is Authority?" In Between Past and Future, edited by H. Arendt. London: Penguin Books, 91-141.

Arendt, Hannah. 1968. “What is Freedom?” In Between Past and Future, edited by H. Arendt. London: Penguin Books, 143-171.

Bataille, George. 1985. "The notion of expenditure." In Visions of Excess, Selected Writings, 1927-1939, edited by Allan Stoekl. Minnesota: University of Minnesota Press, 116-129.

Brown, Wendy. 2000. "Nietzsche for Politics". In Why Nietzsche Still?, edited by Alan D. Schrift. Berkeley and Los Angeles: University of California Press, 205-223.

Caning, Peter. 1990. “How the Fable becomes a World”. In Looking After Nietzsche, edited by Lawrence A. Rieckels. Albany: State University of New York Press, 175-193.

Conway, Daniel, W. 1997. Nietzsche and the Political. Florence, KY: Routledge.

Derrida, Jacques. 1992. The Gift of Death. Chicago: Chicago University Press.

Derrida, Jacques. 1992a. Given Time: 1. Counterfeit Money. Chicago: The University of Chicago Press.

Dombowsky, Don. 2000. “A Response to Alan Schrift's 'Nietzsche for Democracy?'” Nietzsche-Studien (29): 278-290.

Gerhardt, Volker. 1983. “Prinzip des Gleichgewichts”. Nietzsche-Studien (12): 111-133.

Hatab, Lawrence. 1995. A Nietzschean Defense of Democracy. Chicago: Open Court.

Hatab, Lawrence. 2002. “Prospects for a Democratic Agon: Why We Can Still Be Nietzscheans”. In The Journal of Nietzsche Studies (24): 132-147.

Honig, Bonnie. 1993. Political Theory and the Displacement of Politics. Ithaca and London: Cornell University Press.

Horkheimer, Max and Adorno, Theodor W. 2002. Dialectic of Enlightenment. New York: The Continuum Publishing Company.

Kierkegaard, Soren. 1985. Fear and Trembling. London: Penguin Books.

Loreaux, Nicole. 1997. La Cité divisée. L'oublie et la mémoire d'Athènes. Paris : Payot.

MacIntyre, Alasdair. 1984. After Virtue. Notre Dame: Notre Dame University Press.

McIntyre, Alex. 1997. The Sovereignty of Joy: Nietzsche's Vision of Grand Politics. Toronto, Buffalo, London: University of Toronto Press.

Nietzsche, Friedrich. 1968. The Will to Power, edited by Walter Kaufmann. Trans. J. R. Hollingdale and Walter Kaufmann. New York: Vintage Books.

Nietzsche, Friedrich. 1986. Human, All Too Human. Trans. J. R. Hollingdale. Cambridge: Cambridge University Press.

Nietzsche, Friedrich. 1990. Twilight of the Idols. Trans. J. R. Hollingdale. London: Penguin Books.

Nietzsche, Friedrich. 1994. On the Genealogy of Morals. Trans. C. Diethe. Cambridge: Cambridge University Press.

Nietzsche, Friedrich. 1995. Thus Spoke Zarathustra. Trans. Walter Kaufmann. New York: The Modern Library, Random House.

Nietzsche, Friedrich. 1997. Untimely Meditations. Trans. R.J. Hollingdale. Cambridge: Cambridge University Press.

Nietzsche, Friedrich. 2001. The Gay Science. Trans. Josephine Nauckhoff. Cambridge: Cambridge University Press.

Norris, Margot. 1985. Beasts of Modern Imagination, Darwin, Nietzsche, Kafka, Ernst and Lawrence. Baltimore: The John Hopkins University Press.

Owen, David. 2002. “Equality, Democracy, and Self-Respect: Reflections on Nietzsche's Agonal Perfectionism. "The Journal of Nietzsche Studies (24): 113-131.

Sallis, John. 1991. Crossings. Chicago: University of Chicago Press.

Schaap, Sybe. 2002. Die Unfähigkeit zu vergessen. Nietzsche's Umwertung der Wahrheitsfrage. Würzburg: Verlag Königshausen \& Neumann $\mathrm{GmbH}$.

Schrift, Alan D. 2001. "Rethinking the Subject: Or How One Becomes-Other than What One Is". In Nietzsche's Postmoralism, Essays on Nietzsche's Prelude to Philosophy's Future, ed. Richard Schacht. Cambridge: Cambridge University Press, 47-62.

Schrift, Alan, D. 1996. "Rethinking Exchange: Logics of the Gift in Cixous and Nietzsche". Philosophy Today (Spring): 197-205.

Schrift, Alan D. 2000. "Response to Don Dombowsky”. Nietzsche-Studien (29): 291-297. 
Siemens, Herman. 2001. “Agonal Configurations in the Unzeitgemässe Betrachtungen”. Nietzsche-Studien (30): 80-106. Siemens, Herman. 2002. "Agonal Communities of Taste: Law and Community in Nietzsche's Philosophy of Transvaluation”. The Journal of Nietzsche Studies (24): 83-112.

Shapiro, Gary. 1991. Alcyone: Nietzsche on Gifts, Noise and Women. Albany: State University of New York Press.

Stiegler, Barbara. 2001. Nietzsche et la biologie. Paris: Presse Universitaire Francaise.

Villa, Dana. 1996. Arendt and Heidegger. Princeton, New Jersey: Princeton University Press, 80-109.

Villa, Dana. 2000. “Democratizing the Agon: Nietzsche, Arendt, and the Agonistic Tendency in Recent Political Theory". In Why Nietzsche Still?, edited by Alan D. Schrift. Berkeley and Los Angeles: University of California Press, 224-246.

\footnotetext{
Vanessa Lemm es PhD en Filosofía de la New School for Social Research de Nueva York, Estados Unidos. Ha sido profesora e investigadora en las áreas de filosofía y ciencia política en Northwestern University (2002-2005) y también en el European College for Liberal Arts, Berlin (2004-2005). Desde 2006 es profesora investigadora en la escuela de Ciencia Política y en el Instituto de Humanidades de la Universidad Diego Portales, Chile. Actualmente está complementando Nietzsche's Animal Philosophy. On Forgetfulness, Memory and the Becoming of Culture, libro que publicará en el 2007 junto a Fordham University Press.

(E-mail: Vanessa.lemm@prof.udp.cl)
} 
